\title{
Helicobacter pylori Antigen Measurement
}

National Cancer Institute

\section{Source}

National Cancer Institute. Helicobacter pylori Antigen Measurement. NCI Thesaurus.

Code C154819.

The determination of the Helicobacter pylori antigen present in a sample. 